XENOPHON AND THE NAZIS:

A CASE STUDY IN THE POLITICIZATION OF GREEK THOUGHT

THROUGH EDUCATIONAL PROPAGANDA

Helen Roche

Lucy Cavendish College

University of Cambridge

CB3 0BU

hber2@cam.ac.uk 
XENOPHON AND THE NAZIS:

\title{
A CASE STUDY IN THE POLITICIZATION OF GREEK THOUGHT THROUGH EDUCATIONAL PROPAGANDA
}

\begin{abstract}
In National Socialist Germany, radical reinterpretations of Classical texts were always on the agenda. The Reich Education Ministry decreed unequivocally that only those ancient texts which could serve the regime's new 'national-political' education should be taught in schools, and many school-teachers were all too eager to follow this prime directive.

This article will consider a number of articles on Xenophon published in the Nazi Teachers' League (NSLB) Classics journal, Die Alten Sprachen, in order to illuminate the ways in which aspects of Xenophon's thought could become 'politicized'. Thus, one article takes selected passages from Xenophon's Hellenica and weaves them into a treatise on ancient and modern political theory, condemning individualism and providing a systematic indictment of the dangers of democracy, while another elevates aspects of the Spartan constitution to the status of contemporary political principles, placing Sparta (rather than Athens) at the centre of the German political imagination.

As a whole, the article seeks to reveal the contingency of political analysis based on the ancient world, and the ways in which, in certain circumstances, almost any aspect of Greek thought can become 'political'. An authoritarian regime can just as easily style itself as an heir to the legacy of ancient politics as a democratic one, and Greek thought can ultimately be mobilized for almost any ends - however attractive or rebarbative these might seem to observers in today's society.
\end{abstract}




\section{Introduction}

It has become something of a commonplace in classical reception studies to stress the contingency of all readings of Classical texts, along with the reciprocity which exists between these texts, and what subsequent thinkers have made of them: 'From the new narrator's privileged perspective, the past is reconfigured in the light of the new end, and a new order is imposed on history' (Kennedy 1999: 31). Meanwhile, in a bid to dethrone the idea of the 'Classical tradition' from its previous position of romanticized and rarely-questioned pre-eminence, scholars have sought to emphasize the complicity and exclusionary potential of every appeal to the Classical past. ${ }^{1}$ As Miriam Leonard has put it, 'we cannot innocently reread Greek texts and the history of their reception without buying into a certain ideological appropriation' (Leonard 2008a: 119). Such insights sometimes seem to sit rather uneasily with more vindicatory approaches to the discipline, which focus on Classics as 'a marker and maker of historical change [and] of some of the most profoundly constitutive ideologies of modernity' (Porter 2008: 469), or highlight Classical receptions in contexts of dissidence and resistance. ${ }^{2}$

Ultimately, the problem which tends to rear its head can be summarized as follows (to paraphrase Charles Martindale very loosely): 'If [insert Classical author's name here] really means what all later readers have made of him, what are we to do about those readings by figures such as Hitler, Mussolini or Goebbels?'. ${ }^{3}$ Indeed,

\footnotetext{
${ }^{1}$ cf. e.g. Wyke and Biddiss (1999: 13-17); Hardwick (2003: 49); Hardwick and Harrison (2013: xxi).

${ }^{2}$ See Hardwick and Harrison (2013: xxi) for some examples.

${ }^{3}$ cf. Martindale (2008); also Fleming (2008: 129): 'As Harry Schnur suggested in 1970, "Hitler was an evil genius, but not a stupid country bumpkin ... His murderous hates, his racial fantasies, his calculated genocides make him an object of detestation; but do they invalidate his observations on the Pantheon and the Parthenon?"'
} 
Katherine Fleming has explored these problematic tensions at length in her seminal article on 'The use and abuse of antiquity: The politics and morality of appropriation' (2008). How are we to quantify or justify methodologically what constitutes a wholesale 'abuse' - rather than merely a 'use' of Classics, a misappropriation rather than a straightforward 'appropriation'? Fleming concludes that 'moral and intellectual condemnation of [Fascist and National Socialist] returns to antiquity...may become politically necessary, but will always be theoretically gratuitous... The challenge posed by fascism's use of the past...lies in our engagement with it: simply to dismiss [it] is to understand neither the dynamics of that appropriation nor, ultimately, the regime that made it' (Fleming 2008, 130, 137; cf. Morley 2009: 141-2).

It is in this spirit that the following investigation of the educational use of Xenophontic texts during the Third Reich has been conceived. For, as David B. Dennis has rightly noted in his recent study of cultural propaganda in the Nazi Party's official newspaper, the Völkischer Beobachter, there is often a grave danger that we may instinctively find Nazified perspectives on cultural and historical topics so repulsive, far-fetched, or simply bizarre, that we fail to take into account the fact that such ideas did have real power and intellectual influence upon certain sections of the German population (Dennis 2012: 454). We can only conjecture how much more readily such viewpoints may have been absorbed by schoolchildren, who had only ever encountered humanistic or ancient-historical instruction under the aegis of the Third Reich's Nazified curricula. ${ }^{4}$

\footnotetext{
${ }^{4}$ cf. Harloe and Morley (2012: 17), referring to a Thucydidean example: 'A pedagogical article from the [Third Reich], meanwhile..., illustrates the important point that pupils' understandings of the text must have been influenced by their teachers' presentation of it...'
} 
In choosing to focus on National Socialist interpretations of Xenophon, I have two, somewhat interlinked, aims in view. Firstly, as Tim Rood has recently remarked, the reception of historiography is still 'a relatively undeveloped field within the area of classical reception studies' (Rood 2013a: 199) - indeed, some approaches seem to assume a more or less direct antithesis between 'history' and 'reception studies' (cf. Leonard 2008b: 208; Rood 2013a: 209). ${ }^{5}$ However, as both Rood and Neville Morley and Katherine Harloe have noted, there is often more at stake in historiographical appropriations than in those which are purely aesthetic or literary, since 'a naïve, impoverished or disingenuous reading of Homer, Euripides or Virgil might simply result in bad art, whereas a naive, impoverished or mendacious reading of [an ancient historian such as] Thucydides can contribute to significant numbers of people losing their lives.... Even a naive, literal reading can have power - generally, far more power than a self-conscious and sophisticated reading, precisely because it is assumed to bear directly on reality' (Harloe and Morley 2012: 23; cf. Rood 2013a: 201). ${ }^{6}$

Secondly, Xenophon's work has received relatively short shrift during the recent burgeoning of classical reception studies; aside from Rood's manifold

\footnotetext{
${ }^{5} \mathrm{cf}$. Porter $(2008: 474-5,478)$. This assessment is generally borne out by analysis of the contents of recent companions to classical reception studies, such as Hardwick and Stray (2008) - the focus frequently tends to fall on literary, dramatic and cinematographic receptions.

${ }^{6}$ A note here on the relationship which is assumed here between historiography and political thought: following Morley (2014), I would contend that this is more a matter of the attitudes of subsequent readers towards the texts in question, and the presentism or otherwise of said readers' outlook: If the text is deemed useful for the analysis of later political systems (up to and including the present day), particularly in terms of providing fodder for universal rules and generalizations, then it could be said to form part of the canon of political thought, as well as that of historiography (cf. Morley 2014: 148-9,
} 153-6) 
contributions, ${ }^{7}$ Xenophon has thus far come a poor second when compared with Herodotus or Thucydides. ${ }^{8}$ Yet, as Rood's work on Xenophon's reception in the Anglophone world has made abundantly clear, his writing is immensely versatile, and his character can easily be subjected to any number of interpretations - 'from moral exemplum to unpatriotic villain', from 'the "hippie" of the fourth century' to 'Colonel Blimp' (Rood 2016). Not only will this case-study serve to qualify the contention that the twentieth century has tended to denigrate Xenophon rather than admire him (cf. Goldhill 1998), but it also forms an illuminating counterpoise to Rood's extended analysis of the appropriation of the Anabasis in U.S. military culture, 'focusing on some of the dangers inherent in the spell cast by antiquity' (Rood 2010: 4). While Xenophon's American appropriation has been used to bolster the United States' power and prestige both at home and abroad for well over a century, '[projecting] an image of democratic forces bringing the light of freedom to benighted lands' and glorifying Greek democratic courage and discipline in an imperialist cause (Rood 2010: 213), the National Socialist appropriations which we will consider here present a dark mirror image, in which Xenophon can be interpreted as glorifying not only imperial conquest, but also despotic authoritarianism. Thus, the versatility of potential Xenophontic receptions, and the contingency of all such appropriations, can be all the more starkly revealed.

\footnotetext{
${ }^{7}$ cf. Rood (2004, 2010, 2012, 2013a, 2013b, 2015). Additionally, I am most grateful to Professor Rood for supplying me with a copy of his chapter from the forthcoming Cambridge Companion to Xenophon, entitled 'Xenophon's shifting fortunes in the modern world' (2016).

${ }^{8}$ The latter having already had an entire AHRC-funded research project dedicated to the analysis of his enduring influence - cf. Harloe and Morley (2012).
} 
Last but not least, this article aims to provide a contribution to the history of Classical pedagogy and humanistic education during the Third Reich. ${ }^{9}$ Rather than taking the more well-travelled route of focusing on prosopographical or institutional history, this essay aims instead to shed light on how the content of the Classics - and Greek political thought in particular - could be Nazified, by considering articles on Xenophon which were published in Die Alten Sprachen, the official Classical journal of the National Socialist Teachers' League, the NSLB. The periodical was founded in 1936-37 in order to assist teachers to prepare material for classes in a suitably ideological fashion, in the context of the thorough-going scholastic and curricular reforms which the Reich Education Ministry was starting to put into practice (cf. Nagel 2012). In particular, the content of the articles was often supposed to help teachers adhere sufficiently to the 'national-political' demands made by the National Socialist revolution (cf. Nickel 1972). ${ }^{10}$

In a sense, for those who considered themselves to be in tune with the Nazi Weltanschauung, all Greek thought had to be interpreted "politically" during the Third Reich, and, in Party-inspired educational journals such as Die Alten Sprachen,

\footnotetext{
${ }^{9} \mathrm{cf}$. Hardwick and Stray (2008: 4) on the importance of investigating "possible alignments of the history of scholarship with aesthetic and ideological trends outside academia'. Losemann (1977) remains the seminal volume on the Nazification of Altertumswissenschaft in German universities; for a more recent overview and bibliography, see Näf (2001); Malitz $(1998,2006)$ also provides some interesting case-studies from Freiburg University. On humanistic education in the Third Reich in general, see e.g. Apel and Bittner (1994), Bittner (2000, 2001), Fritsch (1982, 2001, 2006), Fuhrmann (1984), Nickel (1970, 1972, 1984), and Kuhlmann (2006).

${ }^{10}$ For a comprehensive analysis of the articles published in Die Alten Sprachen from 1938 onwards, see Roche (2016); on the development of the NSLB's Classical wing (Fachschaft), see also Apel and Bittner (1994). On the NSLB in general, see Feiten (1981).
} 
the blatancy of this politicization is particularly marked - perhaps because it had to be distilled and clarified for a wider readership, rather than being aimed at a purely scholarly audience. I have therefore chosen to analyse the three articles discussed here at some length precisely because they exemplify these Nazified interpretations of Greek texts and historiography. What is more, such interpretations could easily have become a mainstay of the discipline in general and of humanistic pedagogy in particular, had the Third Reich remained in situ for somewhat longer than twelve years, since they were written at a time when the Nazi State - in the guise of Reich Education Minister Bernhard Rust - was constantly increasing its stranglehold on the form and content of Classical education. ${ }^{11}$ While the viewpoints of the authors in question may at times seem rebarbative, and their analyses nothing less than perverse, they nevertheless provide us with a salutary reminder of the ease with which the Classics can be appropriated for any political end, not just as a lynchpin of that common contemporary discourse which unquestioningly glorifies the 'democratic'. 12 Indeed, following Jennifer Roberts' seminal analysis of the long-standing antidemocratic consensus in Western political thought, which predominated at least until the beginning of the nineteenth century (and, in some spheres, well beyond), the readings discussed here could be deemed to fit fairly comfortably into a venerable tradition of critical interpretations of Athenian democracy (Roberts 1994: xi-xii; 3, 6-

\footnotetext{
${ }^{11}$ For more on this, see Roche (2016).

${ }^{12}$ On the dangers of such discourses, often based on generalized and frequently inaccurate 'factoids' which have nevertheless become firmly rooted in the popular imagination, such as 'Ancient Greece was the cradle of democracy', see Hardwick and Harrison (2013: xxxiv-xxxv); also Harloe (2013).
} 
7) ${ }^{13}$ - although, arguably, these National Socialist authors' hostility to the Athenian constitution was ultimately determined by racial rather than by class distinctions.

In this context, focusing on Xenophon, rather than on authors such as Herodotus, Thucydides or Plato (the latter remained the most popular representative of Greek political thought in periodicals of this type) can broaden our perspective on the reception of the political legacies of ancient Greece beyond an appeal to the founding fathers of Western history and philosophy, whilst simultaneously allowing us to engage with these articles' attempts to overturn readers' perceived preconceptions about how such a quintessentially "classroom" author as Xenophon should habitually be taught. ${ }^{14}$ Thus, Xenophon's popularity as a pedagogical resource throughout the ages can usefully be contrasted with these more recent appeals to his (ostensibly underrated) role as a political philosopher. ${ }^{15}$ Since the three articles in

\footnotetext{
${ }^{13}$ Although it is worth noting that more recent studies by scholars such as Oswyn Murray have shown that the eighteenth-century reception of Athens was generally rather more positive than Roberts' survey might suggest (cf. e.g. Murray 2010), it is still the Athens of Solon and the Persian Wars, rather than the Athens of the later Pericles or Cleon, which is most admired (my thanks to Tim Rood for drawing my attention to this point).

${ }^{14}$ While Xenophon's star as a historian and philosopher was still burning brightly in the eighteenth century, when he was often celebrated just as fulsomely as Thucydides, Plato or Herodotus, by the nineteenth century, his reputation had rather begun to wane. See further n. 15 below.

${ }^{15}$ Thus Eduard Bornemann (1940: 163), in particular, emphasizes the fact that Xenophon's work had previously been considered of inferior worth by philologists - including Wilamowitz - because of the perceived gulf between his historical and political writing and that of Thucydides and Plato (for more recent corroborations of this attitude, see Flower [2012: 4]; Harloe and Morley [2012: 9]; Rood [2016] - indeed, such prejudices towards Xenophon were still not infrequently detectable in Anglophone scholarship until fairly recently). Bornemann argues that, instead of constantly being compared with
} 
question deal with three different Xenophontic works - not merely restricting themselves to that schoolroom staple, the Anabasis, ${ }^{16}$ but also providing contemporary reflections on the educational and political uses of the Lac. Pol. and the Hellenica, which had only recently been added to the list of recommended works in Reich Minister Rust's fresh guidelines (cf. Bornemann 1940: 163), they can provide us with a fuller, more rounded perspective on Xenophon's new role in National Socialist Classical pedagogy. ${ }^{17}$

\section{Benedikt Aidelsburger's Anabasis: Xenophon as a Nordic "Führer-personality"}

The first article under discussion, entitled 'Thoughts inspired by a demonstration lesson on Xenophon's Anabasis Book III, Chapters 1 and 2, with a particular evaluation of racial perspectives', was published by Benedikt Aidelsburger in 1937. In one sense, the content of Aidelsburger's essay is perhaps the most predictable, engaging unquestioningly with ideas of Graeco-German racial kinship put forward by

these two 'luminaries' and found wanting, Xenophon should instead be considered on his own terms, not least because his work provides important insights into the world of the average educated Athenian.

${ }^{16}$ cf. Rijksbaron (2002); Flower (2012: 4).

${ }^{17}$ This is not to suggest, of course, that all Classics teachers in the Third Reich would have put such views forward when teaching Xenophontic texts, or even that a majority would have taken them seriously. However, given the articles' provenance in the only Classical journal sponsored by the NSLB, they can at least be taken to represent Nazi pedagogical aspirations - i.e. these readings exemplified how Xenophon should ideally be taught and interpreted according to the National Socialist Weltanschauung. N.B. Unfortunately, I have been unable to discover any concrete information about the lives and careers of two of the authors in question, Benedikt Aidelsburger and Wilhelm Rögels Jürgen Malitz suggests that they were both relatively young, and may possibly have been killed during the Second World War (private correspondence, 28 August 2014). The third author, Adolf Krüger, completed his doctorate on Orphism at the University of Halle in 1934. 
Nazi ideologues such as the infamous Hans Günther, and seeking to emphasize the Nordic warrior spirit of Xenophon and the Greeks under his command. ${ }^{18}$ Yet, at the same time, the fact that the article's subject matter was determined by an actual demonstration lesson given to a group of 15-16 year-old pupils at a training course in Classical pedagogy organized by Gau München-Oberbayern on 11-14 July 1937, entitled 'Nordic Man in Antiquity', gives us a rare opportunity to ascertain how such ideas were ostensibly received by pupils in a classroom situation of sorts - even if this had been simulated especially for the occasion (Aidelsburger 1937: 98-9).

For Aidelsburger, the elucidation of Xenophon's self-description (Anab. III.1.4) found in Plutarch's Praecepta 23 'yields both a succinct appraisal of Xenophon's Führer-personality, as well as an instructive and apposite conceptual definition of the Nordic type of Führertum in itself', thus providing an excellent starting-point for classroom discussions of the passage in question: 'The comparison with our Führer thrusts itself forward irrefutably of its own accord, and...is already instantaneously plausible and realistic to the pupils' (Aidelsburger 1937: 99). ${ }^{19}$ Meanwhile, passages at Anab. III.1.24-25 and III.2.8 are cited to reinforce this parallel, since Aidelsburger believes that they not only present Xenophon as displaying the independence and will to action of a born leader, but also prove that he possesses one of the most characteristic attributes of the Nordic soul - a warlike spirit - along with a refusal to indulge in feeble pact-making with the enemy (Aidelsburger 1937: 99). As further proof of Xenophon's racial awareness, we are presented with an

\footnotetext{
${ }^{18}$ On the prevalence of Güntherian pseudo-scientific theories and terminology in Classical education during this period, see e.g. Apel and Bittner (1994), Roche (2015).

${ }^{19}$ For similar attitudes in another discussion of Xenophon's Anabasis, published in Die Alten Sprachen during the same year, see Schmidt (1937), along with the analysis in Roche (2016).
} 
account of his dealings with the ostensibly Boeotian Apollonides (Anab. III.1.2631), ${ }^{20}$ whom Aidelsburger characterizes as a 'pronounced pacifist, bourgeois appeaser, and a downright defeatist into the bargain', whose alien, near-eastern nonGreekness - as betrayed by his 'Lydian' ear-piercings - Xenophon supposedly depicts with appropriately Aryan disdain (Aidelsburger 1937: 100). ${ }^{21}$

Aidelsburger tops and tails his treatment with a brief summary of the political lessons which he believes can usefully be drawn from his analysis, quoting briefly from Nietzsche's essay 'Wir Philologen' to open the article, and Hitler's Mein Kampf to close it. In Nietzsche's commandment that 'the philologist must understand three things: antiquity, the present, and himself', Aidelsburger sees a reflection of the National Socialist revolution's foremost demand upon each and every Classicist - to discover and bring to the fore those Classical values which can 'provide weapons and munition in the spiritual and political struggles of the present', so that a contemporary humanistic education both can and must become inextricably entwined with the training of the 'political German' (Aidelsburger 1937: 98).

From this perspective, Xenophon's example is of particular contemporary relevance because he fits so exactly both Eichenauer's tripartite model of the Nordic

\footnotetext{
${ }^{20}$ The ethnic identity of Apollonides is left unclear by Xenophon in the original text - while the dialect he spoke was Boeotian, his ears were apparently pierced in the Lydian style; in nineteenth-century German scholarship, therefore, he was often portrayed as a Lydian ex-slave (my thanks to Tim Rood for this point).

${ }^{21}$ Interestingly, Eduard Bornemann, whose article 'Xenophon as a school set-text' generally treats the Anabasis in a much less ideological vein, still stresses the moral and military superiority of the Greeks when compared with the untrustworthy Asiatic hordes, presenting Xenophon's force as bound in racial kinship to the present-day Germans, in an attempt to fulfill the ministerial guidelines to the letter (Bornemann 1940: 164-5).
} 
man of action (fulfilling in equal measure the roles of organizer, Führer and hero), and Günther's spiritual ideal of 'Nordic man', who is possessed above all of an urge to truthfulness in his human dealings and an affinity with knightly justice:

Today we know that a consideration of history which does not include the racial viewpoint and its meaning for all that has happened in the lives of nations and individuals is unthinkable, and equally we know that it is not the masses which make history, but the great personality; namely, the heroic Führer personality. This demonstration lesson should illustrate that...through reading Xenophon, this adherence to the racial viewpoint can be brought fruitfully to the fore (Aidelsburger 1937: 100).

Aidelsburger therefore uses his interpretation of Xenophon's personality and actions, as depicted in the Anabasis, to underpin a Nazified worldview which glorifies dictatorship at the expense of democracy, and sees in every great historical leader or commander a possible paradigm for Hitler himself, whilst also using contemporary racial categories to supplement his analysis of Xenophon's character and motivation. Somewhat fittingly, he concludes his argument with the following Hitlerian quotation: 'For one learns history, not merely to discover what has happened; rather, one learns history, in order to find within it a tutor for the future (Lehrmeisterin für die Zukunft) and for the survival of one's own race' (Aidelsburger 1937: 100, citing Hitler 1943: 468). Ancient history had never seemed so contemporary.

Wilhelm Rögels' Lacedaimoniôn Politeia: Placing Sparta at the Centre of the National Socialist Political Imagination

Wilhelm Rögels' article 'Xenophon's "Staat der Lakedämonier" in Gymnasiumteaching', published in 1940, also takes as its starting-point the exceptional relevance 
of Xenophon's writing for the National Socialist present. Rögels begins by stressing the welcome nature of Minister Rust's changes to the Classics syllabus, which, for the first time, allow a prose work which guarantees such valuable insights into the world of the Spartans and their training to be studied alongside Xenophon's 'campaign memoirs' (Feldzugerinnerungen). ${ }^{22}$ The contrast with Athens' contemporaneous downfall, 'torn to pieces by conflicting factions and the irresponsible goings-on of overambitious demagogues, [lurching] hopelessly into the abyss', can provide a salutary treatment of a historical turning point which Rögels considers to be 'of the highest educational and national-political worth' (Rögels 1940: 138). ${ }^{23}$

Rögels justifies his decision to supplement reading of the Anabasis with the Lac. Pol. - a choice which he believes will be approved of and shared by a large number of his colleagues - with an extended appeal to the similarities between Sparta and the National Socialist state, which resurfaces thematically throughout the article as a whole. From this perspective, Xenophon's description of the Spartan education system is portrayed as particularly instructive:

...here, for the first time in world history, we are confronted with a state which, in the most forceful manner possible, took the education of its polites into its strong hand from their earliest youth, and brought into being a race which, averse to any form of individualism and selfishness, served their state alone (Rögels 1940: 138).

\footnotetext{
${ }^{22}$ Rögels (1940: 138). On the potentially loaded nature of this alternative German translation of the title of the Anabasis, see Schmidt (1937) and Roche (2016).

${ }^{23}$ For analysis of similar views in German ancient historical scholarship during this period, see Näf (1986).
} 
When taken in conjunction with certain passages of Tyrtaian elegy and Plutarch's Life of Lycurgus, ${ }^{24}$ Rögels therefore sees Xenophon's sober depiction of the Spartan world as invaluable in terms of contemporary political education, for, in his attempt to prove to the rest of Greece (and especially the Athenians) that a state should train its citizens thoroughly from a young age in order to guard against the twin threats posed by external enemies and internal corruption, 'the comparison with the present is clear as day' (Rögels 1940: 139-40). Similarities with the Hitler Youth are suggested, and at one point, Rögels even defines Spartan youths as 'Jungmannen' - a term which was not only used on occasion to describe Hitler Youth troops, but which had also become the technical term for all pupils who attended the most prominent type of Nazi eliteschool, the Nationalpolitische Erziehungsanstalten or Napolas. ${ }^{25}$ Once again, Hitler's Mein Kampf is cited in order to lend the parallel some further political legitimacy:

Thus the entire training must be focused so that the youth's free time can be utilized for a useful toughening of the body. He has no right to kick his heels idly during these years...but, after his usual daily work, must steel his young body and make it strong... (Rögels 1940: 140, citing Hitler 1943: 277-8). ${ }^{26}$

The constant competition between youthful members of the Nazi Party organization, and the desire of young Spartans always to be the best and the strongest (hopôs aiei

\footnotetext{
${ }^{24}$ For the importance attached to Plutarch's and Tyrtaios' depictions of Sparta in Nazi educational propaganda, and on Sparta's role in National Socialist thought more generally, see Roche (2012a, 2013a, 2013b).

${ }^{25}$ For more on this, see Roche (2013a), especially p. 211.

${ }^{26}$ On Classics teachers' constant tendency to legitimize their stances by citing Hitler and Mein Kampf, see Nickel (1970).
} 
kratistoi esontai) is also used to evoke comparisons between the Spartan past and the German present, as is the youthful and comradely demeanour of both Spartan and National Socialist citizens, even when advanced in years: 'one is reminded of the disciplined figures which, though greying and careworn from the struggle for life (Lebenskampf), march in the ranks of our own SA' (Rögels 1940: 141).

However, it is not in terms of education alone that Rögels sees Sparta as providing a fitting political model for every aspiring National Socialist. For an education which is rooted in true comradeship and the idea of 'all for one, and one for all' must also, in his view, lead to a type of 'socialism in practice' in everyday life which one seeks vainly in the epochs of history which lie in between, and which thus 'first finds its counterpart in Adolf Hitler's Germany' (Rögels 1940: 141). ${ }^{27}$ With a reference to the contemporary criminal practice of 'hamstering' - when city-dwellers, particularly housewives, would forage in the countryside for items of food, or buy them directly from farmers on the black market, to supplement their ration allowances - Rögels then illustrates this contention as follows:

The principle of 'public interest before private interest' (Gemeinnutz geht vor Eigennutz) made it easy for the inhabitants of 'Lycurgan' Sparta to dispense with money-making opportunities and the accumulation of wealth, while those who still lusted after the 'hamstering' of gold and silver were struck by the full force of the law (Rögels 1940: 141).

\footnotetext{
${ }^{27}$ During the first decades of the twentieth century, Sparta had also been hailed by ancient historians with a Socialist bent as providing a useful historical paradigm - for an example, see Bux (1925). On the more markedly socialist orientation of the NSDAP in its earlier years, see e.g. Nagel (2012: 44) - in fact, Reich Education Minister Bernhard Rust himself was purported once to have hosted a meeting at which Gregor Strasser, Goebbels and others raised the possibility of kicking Hitler out of the Party because his views were too 'petit bourgeois'.
} 
Meanwhile, Rögels claims that the idea that 'the higher the rank, the greater the duty', which every young Hitler Youth leader should have had drilled into his flesh and blood, was realized absolutely in Sparta; the state and the individual were one, and no one who betrayed his people could remain a citizen a moment longer. Similarly, the heroism of Spartan women and mothers, and those left behind on the home front, made sure that no Spartan warrior ever had to go without anything that he needed in battle (Rögels 1940: 141).

Rögels concludes his survey of the Lac. Pol. by emphasising that Xenophon's educational and political usefulness is not to be found in mere comparisons and parallels with the present day, but in the kindred spirit of the Spartans, that "elite of steel-hardened nobility', which will speak directly to pupils' hearts and souls from his writing:

[This is the spirit] which we wish to awaken and strengthen in our youth, that spirit, which reached its consummation in the great Prussian kings and the Prussian nobility of the eighteenth century, which lived on in the army and finally, after decades of entombment, experienced its most glorious resurrection in Adolf Hitler's Germany (Rögels 1940: 142). ${ }^{28}$

Here, we find a Xenophontic text being used both as an endorsement of and a blueprint for the anti-individualistic (and ultimately anti-democratic) policies of the Nazi state - the Greek author becomes in some sense a mouthpiece for both the

\footnotetext{
${ }^{28}$ On the tradition of Spartanism in Prussia, to which Rögels is presumably referring here, see Roche (2012b, 2013a).
} 
nationalist and the socialist tendencies which existed within the National Socialist movement. $^{29}$

\section{Adolf Krüger's Hellenica: Athens and the Evils of Democracy}

The final article under discussion, 'A state-political assessment of the reading of Xenophon's Hellenica' by Adolf Krüger, was published in Die Alten Sprachen in two instalments during 1938 and 1939. In this interpretation, Krüger presents his readers with a reasoned critique of the perils of 'slip-shod democracy' ${ }^{30}$ By analysing three specific passages from the Hellenica - namely Alcibiades' return to Athens, the Arginusae trial and the Revolution in 404, Krüger aims to introduce pupils to this 'era of general decay and destruction' in a way that will suitably heighten their political sensibilities:

\footnotetext{
${ }^{29}$ It is also worth noting that such a reading bears marked similarities to anti-democratic and authoritarian interpretations of Platonic works during this period (my thanks to CRJ's anonymous reader for highlighting this point). Hence, although it would self-evidently be erroneous to speak of a sustained and coherent Nazi ideological or 'doctrinal' approach to the Classics, nevertheless, certain favoured themes and patterns of ideologisation do tend to appear more frequently than others. I hope to examine this phenomenon in far greater depth in my next large-scale research project, provisionally entitled 'The Nazification of the Classics: Humanistic Education in Hitler's Germany', which has been conceived in collaboration with colleagues at the Humboldt-Universität zu Berlin and the Deutsches Institut für Internationale Pädagogische Forschung.

${ }^{30} \mathrm{cf}$. 'Chips' Channon's analysis of Edward VIII's attitude towards the British political system, 22 November 1936: 'He, too, is going the dictator way, and is pro-German, against Russia and against too much slip-shod democracy. I shouldn't be surprised if he aimed at making himself a mild dictator, a difficult task enough for an English King' (Rhodes James 1967: 84).
} 
If Alcibiades' dazzling personality demonstrates that a genius without a higher obligation to the community of his people lives only for himself and for his own power, and the Arginusae trial reveals the moral barbarism and squalidness of an autocratic mob, then the revolution of the year 404 proves that even the nobility was captured by that same self-seeking spirit to which the genius and the masses had become addicted (Krüger 1938: 119).

In his treatment of Alcibiades, ${ }^{31}$ Krüger stresses the extent to which Athenian politicians were constantly - and necessarily - forced into manipulating the masses; however brilliant a demagogue's plans may be, he must capitulate to the moods of the mob, whilst simultaneously finding a way to use them for his own ends (Krüger 1938: 120). This manipulation, which is also clearly visible in the accusations and counteraccusations which surrounded Alcibiades' ostensible profanation of the Eleusinian Mysteries, is seen as all of a piece with the rise of the sophistic spirit, and a concomitant contempt for the rule of law and ancestral religious beliefs. Put simply, individualism had come to dominate over all objective values, and, in his betrayal of his fatherland, Alcibiades reveals himself as a true child of his time: ungovernable, and only concerned with furthering his own power at the expense of the state (Krüger 1938: 120-1).

Krüger goes on to draw parallels with the disadvantages of parliamentary democracy 'which we have experienced for ourselves only too well' during the misrule of the Weimar Republic, with its 'siren call of freedom'. He believes that Germany, too, would have sunk into a deplorable state of Athenian-style ocholocracy, had the German people's desire for unified, authoritarian leadership not made itself felt. Nevertheless, even though he is clearly convinced of the benefits of dictatorship

\footnotetext{
${ }^{31}$ The passages which he treats in detail are Hell. I.4.8-23 and I.5.10-17.
} 
when compared with the dangers of democracy, Krüger does not believe that Alcibiades himself should ever have ruled Athens as a tyrant, given his innate selfishness and lack of concern for the community (Krüger 1938: 121). Ultimately, he holds that Athens suffered not only because of Alcibiades' arrogance, combined with his utter disregard for patriotism and moral and religious convention, but still more because the polis at this time failed to possess any external authority which might 'with diplomatic skilfulness or tyrannical command have tamed such egoistic inclinations..., no power, which might have subordinated the individual will to the collective will of the state. Fundamentally, the polis was still only a sum of individuals, each of whom demanded the right to fulfil his own personal wishes, and none of whom were ready to devote themselves to a higher whole' (Krüger 1938: 122).

Turning to the Arginusae trial, in particular those passages at Hell. I.6.24-35 and I.7.1-35, Krüger does go so far as to praise the heroic spirit of the Athenian forces which joined together (regardless of social standing) to arm a fleet of 110 ships, 'as if now, in the Fatherland's time of need, all selfishness had expired, all discord had vanished, as if finally energy and readiness for self-sacrifice had arrived in Athens! The comparison with Germany in 1914 is obvious' (Krüger: 1938: 122-3). Even the rage of the demos against the accused generals he deems to be psychologically comprehensible, for they were necessarily unable to take their revenge upon the elements, which had actually caused the disaster by making the rescue of the survivors impossible (Krüger 1938: 123).

Nevertheless, Krüger is full of criticism for the ways in which the "democratic" process allowed an unpredictable and easily-manipulated mob to decide 
such far-reaching matters of life or death. In his view, the demos' reception of Euryptolemos' report provides a telling example of this folly:

Here we have the principle of absolute democracy, which believes itself capable of disregarding all other laws in existence, and thus degenerates into despotic rule. Through Euryptolemos' objection, the people felt that a blow had been inflicted upon their selfassurance. The question of whether the generals are guilty or not now withdraws behind the other question, of whether the mass can do what it will. Through his psychological error, which wounded the masses' feeling of selfhood, Euryptolemos achieved exactly the opposite of what he wanted. The people simply would not tolerate a strong personality who dared to oppose their inclinations (Krüger 1938: 125).

Even Socrates comes in for some scathing criticism; Krüger vilifes the philosopher for being a loyal enough citizen to obey the laws of the polis, but not actually being brave enough to speak up for the right outcome in the trial itself. Hence, he too is 'a child of his time', suffering from the very same individualistic tendencies as Alcibiades, although in Socrates' case, these manifest themselves rather differently (Krüger 1938: 126).

Meanwhile, the final judgement of the Athenian democracy in condemning the six generals to death is depicted by Krüger as not even worthy of the description 'a cruel injustice by a strong people', since the demos' subsequent remorse merely indicates the weakness of the moody masses, who are as easily swayed by worthless demagogues or unjust words as by just arguments or true leaders of the people. From this perspective, Krüger sees the fact that the wrong side triumphed in the Arginusae trial as less important than the insight which the debacle can give into the psychological processes of the Athenians, demonstrating in particular their absolute 
dependency on the behaviour and speechifying of their leaders. In his reading, Theramenes and Euryptolemos are both begotten of this era of lies; only the generals, with their soldierly honesty, hint that Athens could possibly have another future, in which an oligarchy might save her from the despotism and capriciousness of the demos (Krüger 1938: 127-8).

In the final section of his analysis (based primarily on Hell. II.1.17-29, II.2.323, and II.3.11-56), Krüger goes on to blame the 'pathos of democratic doctrine' and the hybristic demos for the downfall of the Athenian state, especially since their selection of the incompetent generals who commanded at Aigospotamoi led to Athens' military downfall. Furthermore, he argues that crassly self-centred (democratic) individualism once again ensured that Tydeus and Menander were unprepared to accept Alcibiades' warnings; they wanted to reap all the rewards of victory for themselves alone (Krüger 1939: 36). In more general terms, Krüger sees Athens as the spiritual birthplace of a dangerous new world-view which made a nonsense of any panhellenist aspirations that the Persian Wars might have awoken, elevating instead the principle of 'might makes right'. The Peloponnesian War, which completely destroyed any solidarity or hope of 'national unity' among the Greek states, could in part be seen as the outcome of this development, with Athens as the vat from which a 'ferment of decomposition' was being exported (Krüger 1939: 37).

In this context, it was not Athens, but Sparta, which passed the test of the Peloponnesian War with flying colours - not only did the Spartans spare Athens from destruction and refrain from enslaving her citizens, contenting themselves with making eminently reasonable demands upon their erstwhile rival, but, in so doing, 
they deliberately upheld the 'ancient nomos of the Hellenes'. ${ }^{32}$ While a few of the conquering Spartans - Lysander, for instance - were undoubtedly 'in the grip of the modern spirit', Krüger presents the ephors as the 'conservative protectors of the ancient mores which had made Sparta great' (Krüger 1939: 38). In essence, the tragedy of the Athenian revolution lay in the fact that none of the pro-Spartan oligarchs, not even Kritias himself, were able to escape the toils of that individualism which the democracy had first caused to flourish:

If tyranny by Alcibiades would have plunged Athens into immeasurable catastrophe, then the tyranny of the 'Thirty' proved in practice how disastrously political individualism, which does not even shy away from open treason, must affect the prosperity of the entire state. As Alcibiades betrayed his father-city to Sparta, in order to attain personal power through Sparta, so the thirty tyrants summoned the Spartans into their own city, in order to obtain a prop for their despotism... The ruthless eradication of all internal opposition not only lacked any form of diplomatic discretion (which even Theramenes possessed), but furthermore contradicted all the requirements which the good of the entire state required of its political leaders. If the soldierly bearing of the generals in the Arginusae trial gave hope that the salvation of the state might lie with the oligarchy, now the self-serving and treasonous goings-on of the 'Thirty' have removed this hope and shown with terrifying clarity their inability to think in truly statepolitical terms. Then where should we now find the bearers of an unselfish attitude to the state, which would be ready to place the good of the community before the good of the individual? That no strong feeling for the state could be built upon the arbitrary rule of the

\footnotetext{
${ }^{32}$ Krüger cites Hell. II.2.20 as proof of the Spartans' respect for their mutual brotherhood-in-arms against the Persians, borne from their joint Greek ancestry. He rejects unequivocally the idea (put forward by Beloch) that this was actually part of a cunning manoeuvre to use Athens as a bulwark against faithless Thebes: 'We do not need to call the Spartans' openness into question...' (Krüger 1939: 37).
} 
people has been demonstrated by the Arginusae trial. But geniuses and the nobility sought their own private gain too: Alcibiades and the 'Thirty' attest to that much. (Krüger 1939: 423)

The tacit moral of the story seems to suggest that, once again, National Socialist teachers and pupils should look to Sparta herself as a political role model, rather than attempting to emulate the corrupt, vacillatory, and treasonous political atmosphere engendered by the Athenian democratic experiment.

\section{Conclusions}

By examining these three National Socialist authors' approaches to Xenophon in depth, I would argue that we gain something more than a mere appreciation of the ways in which Greek political thought could variously be 'misappropriated' under a fascist regime. For if, as Lorna Hardwick has cogently argued, classical reception studies can potentially 'frame new questions or retrieve aspects of the source which have been marginalized or forgotten' (Hardwick 2003: 4), then the receptions discussed here can perhaps also provide a perspective which draws attention towards facets of Xenophon's thought which are less 'rhetorically or emotionally attractive' to the current, overwhelmingly democratic Zeitgeist (cf. Hardwick and Harrison 2013: xxxiv-xxxv; Harloe 2013: 8). ${ }^{33}$

\footnotetext{
${ }^{33}$ Interestingly, as Rood has noted, there seems to be a marked diversion between views of Xenophon among ancient historians, who have rarely shied away from considering the overtly anti-democratic elements of his oeuvre, and views among scholars of political thought, particularly in the U.S. (and especially those with a Straussian connection), who favour ironic readings of the Lac. Pol., whilst simultaneously stressing the importance for Xenophon of Socrates and Athens, and focusing on the pro-democratic facets of the Anabasis, casting the author as a committed democrat (cf. Rood 2015).
} 
Thus - just to take one example - Krüger's highly negative view of the misconduct of Athenian aristocrats, whom he sees as contributing both to the loss of the Peloponnesian War and to Athens' ultimate downfall, also find their mirror in some of the material presented in Roberts' survey of the anti-democratic tradition (cf. Roberts 1994: 14) - even if Krüger's remarks on the subject are framed somewhat differently. Indeed, according to Roberts' epilogue, the hostility of twentieth century totalitarian regimes (including Nazism) towards Athenian democracy can in some measure explain the current positive hold which this form of ancient Greek government now exerts upon the popular imagination (Roberts 1994: 291, 294-5). Moreover, it is worth noting that, while weaker contributions (such as Aidelsburger's) merely tend to use Xenophon's writing for current political ends, cherry-picking those facts about the ancient Greek world which Xenophon presents in order to prove him a dedicated National Socialist or a pure-blooded Aryan avant la lettre, more sophisticated interpretations (such as Krüger's) seem to engage at least implicitly with Xenophon's own political sympathies - thus, we can see that even texts as ideological as those discussed here can contain certain gradations of subtlety. ${ }^{34}$

\footnotetext{
${ }^{34}$ See also n. 15 above; Manfred Bornemann's remarks upon the importance of considering Xenophon on his own terms can also be seen as eminently sensible - even though these remarks might initially be considered mere political sycophancy, given the context in which they were made. Certainly, it seems dangerous simply to dismiss all contributions to Die Alten Sprachen as quintessentially 'fascist' readings without any further relevance - often, a veneer of ideology seems to be used merely as a sop to the editors in the hope of guaranteeing publication, whilst the majority of the article puts forward a seemingly unexceptionable and well-founded scholarly argument (cf. Roche 2016 for more on such ideological 'sandwich jobs', which were also very common in the later German Democratic Republic this time in the service of Communist ideology).
} 
At the same time, the not infrequently crude and/or excessive attempts made by Aidelsburger, Rögels and Krüger to peremptorily assimilate these texts to contemporary concerns (cf. Martindale 2008: 5) can, as Hardwick has also noted, provide 'a salutary warning to any who are tempted to selectively emphasize...relationships between ancient and modern in the hope of preserving interest in classical subjects, or who allow reception studies to become disengaged from critical enquiry into the relationship between the analogue ancient and modern texts or images' (Hardwick 2003: 49). It is no coincidence, perhaps, that for the first year of its existence, the journal in which these articles were published bore the title Gegenwärtiges Altertum (Contemporary Antiquity). One might even go so far as to suggest that, to a certain extent, these National Socialist interpretations not only represent a type of 'reactionary modernism' (cf. Herf 1984), but also advocate a form of 'classicising modernism', in which any nineteenth-century tendencies to treat the Classical as having little or no relevance whatsoever to the 'modern' (cf. Morley 2009; Vlassopoulos 2011; Harloe and Morley 2012: 2) were utterly discarded. After all, it was Hitler himself who had proclaimed history as the ideal 'Lehrmeisterin für die Zukunft' (Hitler 1943: 468); the idea of historia magistra vitae could thus reign sovereign once again. Now, the Classics were no longer seen as 'untimely', but rather as of the timeliest - antiquity constantly had to be understood through the lens of the present, rather than being ultimately estranged from it.

Finally, although it might be easy (or easier?) 'to dismiss the [Xenophon of the Nazi teachers' league] as the product of a naïve, partial and dehistoricized reading of the text[s in question]..., this misses the point: the idea of [Xenophon], however far removed it may be from a complex reality, [had] continuing power and 
currency'. ${ }^{35}$ Thus, we might conclude - perhaps with even more conviction than Rood has done in an earlier issue of this journal (2013a: 209) - that 'the construction of different sorts of Xenophon' is a historical and historiographical matter of some considerable importance - not least because of the insight which, in this instance, such receptions can grant us into the dynamics of National Socialist pedagogy and historical consciousness during the Third Reich.

\section{Bibliography}

B. Aidelsburger, 'Gedankengang einer Lehrprobe über Xenophons Anabasis, Buch III, Kapitel 1 und 2, unter besonderer Auswertung des rassischen Gesichtspunktes', Die Alten Sprachen 2 (1937), pp. 98100.

H.-J. Apel and S. Bittner, Humanistische Schulbildung 1890-1945. Anspruch und Wirklichkeit der altertumskundlichen Unterrichtsfächer (Köln: Böhlau, 1994).

S. Bittner, 'Eine Rassengemeinschaft nationalsozialistischer Persönlichkeiten. Parteiamtliche Phantasmagorie, Erziehungstheorie und pädagogische Praxis', in J. Henseler and J. Reyer (eds), Sozialpädagogik und Gemeinschaft: Historische Beiträge zur Rekonstruktion eines konstitutiven Verhältnisses (Göppingen: Schneider Verlag Hohengehren, 2000), pp. 150-65.

---, 'Die Entwicklung des althistorischen Unterrichts zur Zeit des Nationalsozialismus', in B. Näf (ed.), Antike und Altertumswissenschaft in der Zeit von Faschismus und Nationalsozialismus (Mandelbachtal and Cambridge: Edition Cicero, 2001), pp. 285-303.

E. Bornemann, 'Xenophon als Schullektüre', Die Alten Sprachen 5 (1940), pp. 163-6.

E. Bux, 'Zwei sozialistische Novellen bei Plutarch', Klio 19 (1925), pp. 413-31.

D. B. Dennis, Inhumanities: Nazi Interpretations of Western Culture (Cambridge: Cambridge University Press, 2012).

\footnotetext{
${ }^{35}$ Here, I paraphrase Harloe and Morley's analysis of American neoconservative readings of Thucydides (2012: 11-12).
} 
W. Feiten, Der Nationalsozialistische Lehrerbund. Entwicklung und Organisation: Ein Beitrag zum Aufbau und zur Organisationsstruktur des nationalsozialistischen Herrschaftssystems (Weinheim: Beltz, 1981).

K. Fleming, 'The Use and Abuse of Antiquity: The Politics and Morality of Appropriation', in C. Martindale and R. F. Thomas (eds), Classics and the Uses of Reception (Oxford: Blackwell, 2008), pp. 127-37.

M. A. Flower, Xenophon's Anabasis or The Expedition of Cyrus (Oxford: Oxford University Press, 2012).

A. Fritsch, 'Der Lateinunterricht in der Zeit des Nationalsozialismus - Organisation, Richtlinien, Lehrbücher', Der Altsprachliche Unterricht 25 (1982), pp. 20-56.

---, 'Die altsprachlichen Fächer im nationalsozialistischen Schulsystem', in R. Dithmar and A. Schwalb (eds), Schule und Unterricht im Dritten Reich (Ludwigsfelde: Ludwigsfelder Verlagshaus, 2001), pp. $153-88$.

---, 'Zur Entwicklung der Didaktik des altsprachlichen Unterrichts im Nationalsozialismus', in S. Doff and A. Wegner (eds), Fremdsprachendidaktik im 20. Jahrhundert. Konstituierung einer wissenschaftichen Disziplin im Spannungsfeld von Theorie und Praxis (Berlin: Langenscheidt, 2006), pp. 209-24.

M. Fuhrmann, 'Die humanistische Bildungstradition im Dritten Reich', Humanistische Bildung 8 (1984), pp. 139-61.

S. Goldhill, 'Review of V. J. Gray (1998), The Framing of Socrates: The Literary Interpretation of Xenophon's 'Memorabilia”, BMCR 12.08. (1998): http://bmcr.brynmawr.edu/1998/1998-12-08.html.

L. Hardwick, Reception Studies (Oxford: Oxford University Press, 2003).

L. Hardwick and C. Stray (eds), A Companion to Classical Receptions (Oxford: Blackwell, 2008).

L. Hardwick and S. Harrison (eds), Classics in the Modern World: A 'Democratic Turn'? (Oxford: Oxford University Press, 2013).

K. Harloe and N. Morley (eds), Thucydides and the Modern World: Reception, Reinterpretation and Influence from the Renaissance to the Present (Cambridge: Cambridge University Press, 2012).

K. Harloe, 'Questioning the Democratic, and Democratic Questioning', in L. Hardwick and S. Harrison (eds), Classics in the Modern World: A 'Democratic Turn'? (Oxford: Oxford University Press, 2013), pp. 3-13. 
J. Herf, Reactionary Modernism: Technology, Culture and Politics in Weimar and the Third Reich (Cambridge: Cambridge University Press, 1984).

A. Hitler, Mein Kampf (München: Eher Verlag, 1943).

D. F. Kennedy, 'A Sense of Place: Rome, History and Empire Revisited', in C. Edwards (ed.), Roman Presences: Receptions of Rome in European Culture, 1789-1945 (Cambridge: Cambridge University Press, 1999), pp. 19-34.

A. Krüger, 'Staatspolitische Auswertung der Lektüre von Xenophons Hellenika', Die Alten Sprachen 3 (1938), pp. 119-28; Die Alten Sprachen 4 (1939), pp. 36-43.

P. Kuhlmann, 'Humanismus und Alte Sprachen im Dritten Reich', Archiv für Kulturgeschichte 88 (2006), pp. 409-32.

M. Leonard, 'The Uses of Reception: Derrida and the Historical Imperative', in C. Martindale and R. F. Thomas (eds), Classics and the Uses of Reception (Oxford: Blackwell, 2008a), pp. 116-26.

---, 'History and Theory: Moses and Monotheism and the Historiography of the Repressed', in L. Hardwick and C. Stray (eds), A Companion to Classical Receptions (Oxford: Blackwell, 2008b), pp. 207-18.

V. Losemann, Nationalsozialismus und Antike. Studien zur Entwicklung des Faches Alte Geschichte 1933-1945 (Hamburg: Hoffmann und Campe, 1977).

J. Malitz, 'Römertum im "Dritten Reich": Hans Oppermann', in P. Kneissl and V. Losemann (eds), Imperium Romanum. Studien zu Geschichte und Rezeption. Festschrift für Karl Christ zum 75. Geburtstag (Stuttgart: Steiner, 1998), pp. 519-43.

---, 'Klassische Philologie', in E. Wirbelauer, F.-R. Hausmann, and S. Paletschek (eds), Die Freiburger Philosophische Fakultät 1920-1960: Mitglieder - Strukturen - Vernetzungen (Freiburg: Karl Alber Verlag, 2006), pp. 303-64.

C. Martindale, 'Introduction: Thinking through Reception', in C. Martindale and R. F. Thomas (eds), Classics and the Uses of Reception (Oxford: Blackwell, 2008), pp. 1-13.

N. Morley, Antiquity and Modernity (Oxford: Wiley-Blackwell, 2009).

---, Thucydides and the Idea of History (London: I.B. Tauris, 2014).

O. Murray, 'Modern Perceptions of Ancient Realities from Montesquieu to Mill', in M. H. Hansen (ed.), Démocratie athénienne - démocratie moderne: tradition et influences (Geneva: Fondation Hardt, 2010), pp. 137-66. 
B. Näf, Von Perikles zu Hitler? Die athenische Demokratie und die deutsche Althistorie bis 1945 (Bern: Peter Lang, 1986).

B. Näf (ed.), Antike und Altertumswissenschaft in der Zeit von Faschismus und Nationalsozialismus (Mandelbachtal and Cambridge: Edition Cicero, 2001).

A. C. Nagel, Hitlers Bildungsreformer: Das Reichsministerium für Wissenschaft, Erziehung und Volksbildung, 1934-1945 (Frankfurt am Main: Fischer, 2012).

R. Nickel, 'Der Mythos vom Dritten Reich und seinem Führer in der Ideologie des humanistischen Gymnasiums vor 1945', Paedagogica Historica: International Journal of the History of Education 10 (1970), pp. 111-28.

---, 'Humanistisches Gymnasium und Nationalsozialismus. Erziehung zum Rassenbewusstsein im altsprachlichen Unterricht vor 1945', Paedagogica Historica: International Journal of the History of Education 12 (1972), pp. 485-503.

---, 'Angepaßte Didaktik. Alte Sprachen und Nationalsozialismus', Pädagogische Rundschau 38 (1984), pp. 85-102.

J. I. Porter, 'Reception Studies: Future Prospects', in L. Hardwick and C. Stray (eds), A Companion to Classical Receptions (Oxford: Blackwell, 2008), pp. 469-81.

R. Rhodes James, Chips: The Diaries of Sir Henry Channon (London: Weidenfeld and Nicolson, 1967).

A. Rijksbaron, 'The Xenophon Factory: One Hundred and Fifty Years of School Editions of Xenophon's Anabasis', in R. K. Gibson and C. Shuttleworth Kraus (eds), The Classical Commentary: Histories, Practices, Theory (Leiden: Brill, 2002), pp. 235-67.

J. T. Roberts, Athens on Trial: The Antidemocratic Tradition in Western Thought (Princeton: Princeton University Press, 1994).

H. B. E. Roche, 'Spartanische Pimpfe: The Importance of Sparta in the Educational Ideology of the Adolf Hitler Schools', in S. Hodkinson and I. Macgregor Morris (eds), Sparta in Modern Thought: Politics, History and Culture (Swansea: Classical Press of Wales, 2012a), pp. 315-42.

---, "'Go, tell the Prussians...": The Spartan Paradigm in Prussian Military Thought during the Long Nineteenth Century', New Voices in Classical Reception Studies 7 (2012b), pp. 25-39. 
---, Sparta's German Children: The Ideal of Ancient Sparta in the Royal Prussian Cadet-Corps, 18181920, and in National Socialist Elite Schools (the Napolas), 1933-1945 (Swansea: Classical Press of Wales, 2013a).

---, "'In Sparta fühlte ich mich wie in einer deutschen Stadt" (Goebbels): The Leaders of the Third Reich and the Spartan Nationalist Paradigm', in F. Rash, G. Horan, and D. Wildmann (eds), English and German Nationalist and Anti-Semitic Discourse, 1871-1945 (Oxford: Peter Lang, 2013b), pp. 91115.

---, 'Blüte und Zerfall: "Schematic Narrative Templates" of Decline and Fall in völkisch and National Socialist Racial Ideology', in L. Day and O. Haag (eds), The Persistence of Race from the Wilhelmine Empire to National Socialism: Re-examining Constructions and Perceptions of Cultural Narratives of Race in German History, 1871-1945 (Oxford: Berghahn, 2015, forthcoming).

---, 'Classics and Education in the Third Reich: Die Alten Sprachen and the Nazification of Latin- and Greek-teaching in Secondary Schools', in H. B. E. Roche and K. Demetriou (eds), The Classics, Fascism, and Nazi Ideology: A Companion (Leiden: Brill, 2016, forthcoming).

W. Rögels, 'Xenophons "Staat der Lakedämonier" im Gymnasialunterricht', Die Alten Sprachen 5 (1940), pp. 138-42.

T. C. B. Rood, The Sea! The Sea! The Shout of the Ten Thousand in the Modern Imagination (London: Duckworth Overlook, 2004).

---, American Anabasis: Xenophon and the Idea of America from the Mexican War to Iraq (London: Duckworth Overlook, 2010).

---, 'A Delightful Retreat: Xenophon and the Picturesque', in F. Hobden and C. J. Tuplin (eds), Xenophon: Ethical Principles and Historical Enquiry (Leiden: Brill, 2012), pp. 89-121.

---, 'Redeeming Xenophon: Historiographical Reception and the Transhistorical', Classical Receptions Journal 5 (2013a), pp. 199-211.

---, 'Xenophon and the Barberini: Pietro da Cortona's Sacrifice to Diana', Journal of the Warburg and Courtauld Institutes 76 (2013b), pp. 1-22.

---, 'Political Thought in Xenophon: Straussian Readings of the Anabasis', Polis: the Journal for Ancient Greek Political Thought 32 (2015), 143-65.

---, 'Xenophon's Shifting Fortunes in the Modern World', in M. A. Flower (ed.), The Cambridge Companion to Xenophon (Cambridge: Cambridge University Press, 2016, forthcoming). 
K. Schmidt, 'Xenophons Feldzugerinnerungen im Unterricht der nationalsozialistischen Schule', Die Alten Sprachen 2 (1937), pp. 14-20.

K. Vlassopoulos, 'Acquiring (a) historicity: Greek History, Temporalities and Eurocentrism in the Sattelzeit (1750-1850)', in A. Lianeri (ed.), The Western Time of Ancient History: Historiographical Encounters with the Greek and Roman Pasts (Cambridge: Cambridge University Press, 2011), pp. 15678.

M. Wyke and M. Biddiss (eds), The Uses and Abuses of Antiquity (Bern: Peter Lang, 1999). 